$\begin{gathered}\text { Revista do Departamento de Geografia } \\ \text { Universidade de São Paulo } \\ \text { www.revistas.usp.br/rdg } \\ \text { Volume Especial (2016) }\end{gathered}$
ISSN 2236-2878

\title{
AVALIAÇÃO DO SUBCANAL FÍSICO-QUÍMICO EM DUQUE DE CAXIAS (RJ): A INFLUÊNCIA DAS POLÍTICAS MUNICIPAIS DE ORDENAMENTO TERRITORIAL NO CLIMA URBANO
}

\author{
EVALUATION OF PHYSICAL-CHEMISTRY SUBCHANNEL AT DUQUE DE CAXIAS (RJ): \\ THE INFLUENCE OF LOCAL POLICIES OF \\ TERRITORIAL MANAGEMENT ON URBAN CLIMATE
}

\author{
Antonio Carlos da Silva Oscar Júnior \\ Universidade do Estado do Rio de Janeiro \\ ac_oscar@outlook.com
}

Resumo: Mesmo com toda regulamentação em nível federal e estadual no que tange ao disciplinamento do uso e ordenamento territorial, sobretudo quanto à localização industrial, no Município de Duque de Caxias ainda é comum a ocorrência de conflitos de uso. Neste sentido, o presente artigo buscou avaliar a qualidade do ar neste território (entre 2004 e 2009) através dos dados diários e horários das estações automáticas do INEA, considerando o parâmetro Partículas Totais em Suspensão - PTS. Pra tal, testes estatísticos como: Mann-Kendall, Matriz de dispersão e Boxplot foram aplicados, e associados ao mapeamento das indústrias potencialmente poluidoras do Município, frota de veículos e evolução urbanística. Os resultados apontam para tendência diária positiva para as estações Jardim Primavera e Pilar; predominância dos eventos mais relevantes de concentração no período da noite e tarde; bem como, correlação positiva, em quase todos os anos, entre a estação Campos Elíseos, onde se localiza a atividade petroquímica, e as demais estações. Além disso, chama atenção a expansão da atividade logística no Município que ao demandar o crescente trânsito de veículos automotores pode contribuir significativamente com a deteriorização da qualidade do ar na área de estudo.

Palavras-chave: Qualidade do ar, Clima urbano, Planejamento urbano.
Abstract: Even with all regulations at the federal and state level with regarding to disciplining the land use and territorial management, particularly as the industrial location, in Duque de Caxias is still common the occurrence of conflicts of use. In this sense, this article aims to evaluate the air quality in this territory between 2004 and 2009 through the daily and hourly data of automatic stations of INEA, considering as parameter Total Particles in Suspension - TSP. For this, statistical tests such as Mann-Kendall, dispersion matrix and Box plot was applied together with the mapping of potentially polluting industries, car fleet and urbanistic data. The results show a positive daily trend for the stations Jardim Primavera and Pilar; predominance of the most important events of concentration in the evening and night; as well as positive correlation, in almost years, between Campos Elíseos station, where is the petrochemical activity, and other stations. In addition, attention should be paid to expansion of logistics activities in the municipality, it demands increasing of motor vehicle traffic that could contribute to the deterioration of air quality in the study area.

Keywords: Air quality, Urban climate, Urban management. 


\section{INTRODUÇÃO}

Em 2015 a Organização Mundial de Saúde (OMS) divulgou resultados a respeito dos efeitos da poluição atmosférica na saúde humana, no qual se concluiu que aproximadamente sete milhões de pessoas morrem, anualmente, devido esse fator de risco. Dos problemas relacionados à poluição atmosférica diversos estudos já apontam correlação positiva entre os problemas de cardiopatia e respiratórios, sendo o último, o quarto grupo de doenças que mais provoca mortes no mundo (LIN et al., 1999; DEVLIN et al., 2003; RHODEN et al., 2005; VERSOUKIS et al., 2009), reverberando inclusive em vultosas perdas econômicas.

É indubitável a correlação desta realidade com a forma de desenvolvimento trilhada pelas nações. Desde a primeira revolução industrial, alterando os paradigmas econômicos e produtivos, promovem-se alterações na forma como nos organizamos social e espacialmente, gerando excedentes diversos, entre eles o material que encontra na atmosfera seu destino, dada a combustão incompleta, seja dos veículos automotores ou das chaminés das indústrias.

A cidade, um fenômeno social, econômico, político, remodela o espaço com sua lógica particular, sendo também diferenciada nas diversas partes do mundo. Nos países hoje conhecidos como desenvolvidos, outrora ${ }^{1}$, os centros urbanos foram abandonados pelas classes média e alta que procuraram no subúrbio seu refúgio, fugindo justamente dos inconvenientes problemas urbanos decorrentes desse processo, entre eles a poluição. Já nos latino-americanos, comumente de industrialização tardia, as áreas nobres foram preservadas, obrigando as indústrias pesadas a localizar-se nos subúrbios, que aqui, diferente dos países desenvolvidos, representam bolsões de carência social, econômica e de infraestrutura. Revela-se assim uma coerente correlação entre a poluição e os fatores socioeconômicos e espaciais.

O Município de Duque de Caxias, localizado na Região Metropolitana do Rio de Janeiro (RMRJ), a partir da construção da BR040 (Rodovia Washington Luiz) em 1920 e posterior recebimento da Fábrica Nacional de Motores (FNM), é importante área de estudo, visto que seu desenvolvimento industrial e logístico foi impulsionado em 1961 com a instalação do atual Polo Petroquímico da Petrobras, conhecido como REDUC e mais recentemente pela abertura do Arco Metropolitano. Tais opções (ou imposições ${ }^{2}$ ) econômicas, associadas ao seu relevo particular, deprimido, dificultador da adequada dispersão dos poluentes que porventura fossem lançados na atmosfera, compõe contexto adequado para avaliações no contexto do canal físico-químico da teoria do Clima Urbano, conforme proposta de Monteiro (1976).

O Professor Carlos Augusto Figueiredo Monteiro lançou sua proposta Teórica do Sistema Clima Urbano para nortear aqueles que pretendiam se debruçar sobre a temática, tornando essa obra, Teoria e Clima Urbano, referência para a Climatologia nacional produzida por Geógrafos. No estudo são propostos dez enunciados básicos, dentre os quais se destaca o primeiro deles, verdadeiro norte: "O clima urbano é um sistema que abrange o clima de um dado espaço terrestre e sua urbanização" (MONTEIRO, 1976:95) e a partir daí vê-se o clima urbano do ponto de vista sistêmico, baseado na Teoria Geral dos Sistemas, no qual se inclui como partes importantes da sua estrutura o natural e o construído pelo homem.

A partir dessa obra, evoluindo na concepção sorreriana, se dá grande importância aos processos físico-químicos característicos da atmosfera que desencadeiam os tipos de tempo e o clima através dos fluxos de energia, iniciados a partir da entrada da energia solar (input) e comandadas pelas componentes dinâmicas determinadas pela circulação atmosférica. Esses fluxos ao encontrar o ambiente urbano e suas características peculiares favorecem a transformação dessa energia e sua posterior saída na forma de enchentes, poluição e ilhas de calor (output).

Tamanho é o poder decisivo do homem como operando do S. C. U, que graças a seu poder de decisão ele pode intervir e adaptar o seu funcionamento tornando este passível de auto-regulação. Outro indício de sua posição de destaque é o fato dos produtos do S.C.U. focalizarem preferencialmente nos canais (sensoriais) de percepção humana. Assim, os processos que se iniciam essencialmente na atmosfera reconhecem o homem como referencial dos problemas e valores dos fatos geográficos. Baseando-se nisso Monteiro (1976) propõem 3 canais de percepção: o conforto térmico, a qualidade do ar e os impactos meteóricos. Marandola Jr (2009) também aponta a população, ou seja, o homem, como componente

\footnotetext{
${ }^{1}$ Atualmente, o processo de gentrificação (ver Bataller, 2000) tem promovido alteração nessa lógica espacial ao estimular a valorização e revitalização econômica dos centros urbanos.

${ }^{2}$ Usamos o termo imposições, visto que grande parte dos equipamentos, ambientalmente danosos, foram instalados em momentos de cerceamento do estado democrático.
} 
essencial para o entendimento das discussões recentes sobre o clima, pois esses atuam tanto como produtores/causadores de distúrbios, assim como alvo dos danos e impactos, sobre tudo em nível local.

Há que considerar no bojo desse complexo sistema operado pelo homem, a interferência das políticas públicas na dinâmica territorial, atuando ativamente nas práticas espaciais, interferem significativamente na seletividade espacial (CORRÊA, 2008). Assim, como defende o professor Monteiro, cabe à Climatologia produzida por geógrafos a compreensão dos fenômenos atmosféricos que encontram na superfície terrestre e organização territorial seu fim, portanto, a existência de marcos regulatórios e seu reflexo espacial emergem como importante pauta de estudo no âmbito dos estudos do Clima Urbano.

Além disso, estes marcos, quando não favorecem a construção de uma política adequada de ordenamento territorial e gestão dos conflitos de uso, sobrepujando, em diversos pontos do território, interesses econômicos aos interesses da população, intensifica a exposição dessa população aos riscos tecnológicos, entre eles, à poluição atmosférica. Tal constatação corrobora a importância deste estudo, bem como, resgata uma discussão própria da geografia do clima (SANT'ANNA NETO, 2001), que segundo o autor deve:

(...) "necessariamente, compreender que a repercussão dos fenômenos atmosféricos na superfície terrestre se dá num território, em grande parte, transformado e produzido pela sociedade de maneira desigual e apropriado segundo os interesses dos agentes sociais.

O modo de produção capitalista territorializa distintas formas de uso e ocupação do espaço, definidas por uma lógica que não atende aos critérios técnicos do desenvolvimento (ou sociedades) sustentáveis. Assim, o efeito dos tipos de tempo sobre um espaço construído de maneira desigual gera problemas de origem climáticas também desiguais” (p.: 58).

Isso posto, o ar urbano, uma mistura de poluentes que encadeiam efeitos entre si e aumentam a exposição das pessoas aos efeitos de outros poluentes, graças as práticas espaciais, norteadas significativamente pelas políticas públicas, é causa e efeito do processo de ordenamento territorial e da (má) gestão urbana.

Muitos já são os efeitos identificados da poluição à saúde humana. Cançado et al. (2006) argumenta que a exposição ao $\mathrm{CO}$ causa lentidão dos reflexos e sonolência, uma vez que suas moléculas se ligam à hemoglobina reduzindo a quantidade de oxigênio que transportam os glóbulos vermelhos. $\mathrm{O}$ NO2 pode agravar a asma e reduzir as funções do pulmão, como também tornar as vias respiratórias mais sensíveis a alérgicos. O O3 também causa inflamação do pulmão, reduzindo suas funções e capacidade. Já os particulados menores, especialmente aqueles com 10 micrômetros de diâmetro ou menores, podem se alojar nos alvéolos do pulmão.

Estudos como de Braga et al. (2007) e Martins et al. (2002), mostram a correlação estatística entre o aumento do material particulado em suspensão na atmosfera e as internações por doenças cardiovasculares e respiratórias. O primeiro estudo enfoca o caso de Itabira (MG) mostrando que aumentos de $10 \mu \mathrm{g} / \mathrm{m} 3$ no PM10 podem estar associados com aumentos de até $12 \%$ nos atendimentos de pronto-socorro por doenças respiratórias (para crianças menores de 13 anos), já por doenças cardiovasculares o efeito foi agudo principalmente para os indivíduos com idade entre 45 e 64 anos. $O$ segundo estudo observa que um aumento interquartil (25\%-75\%) para o O3 $(38,80 \mu \mathrm{g} / \mathrm{m} 3)$ e SO2 $(15,05 \mu \mathrm{g} / \mathrm{m} 3)$ levou a um acréscimo de $8,07 \%$ e $14,51 \%$, respectivamente, no número de atendimentos por pneumonia e gripe em idosos de São Paulo.

O Instituto Estadual do Ambiente do Rio de Janeiro (INEA), em seus relatórios de Avaliação da Qualidade do Ar, divulga um quadro sintético (Figura 1) dos principais poluentes urbanos, suas fontes e efeitos a saúde humana. Por estes efeitos, diversas agências reguladoras fixam os limites aceitáveis destes na atmosfera local, reconhecendo a impossibilidade de tornar nula as emissões atmosféricas, fixam-se máximos aceitáveis, os quais são variáveis de acordo com cada agência regulatória.

A partir da síntese expressa na Figura 1, observa-se a expoente contribuição da combustão incompleta que ocorre nos motores das fontes moveis, bem como, as atividades industriais, sobretudo aquelas relacionadas à atividade petroquímica, tão comum no Município em questão. Nesse sentido, o presente estudo pretende oferecer uma leitura do Subcanal físico-químico, no contexto da Teoria e Clima Urbano, para o Município de Duque de Caxias, pondo luz ao papel das políticas públicas no processo de gestão dos riscos ambientais, as quais deveriam ser (mas nem sempre é) orientadas à redução da exposição da população a agentes de ameaça, tal como gases poluentes. 


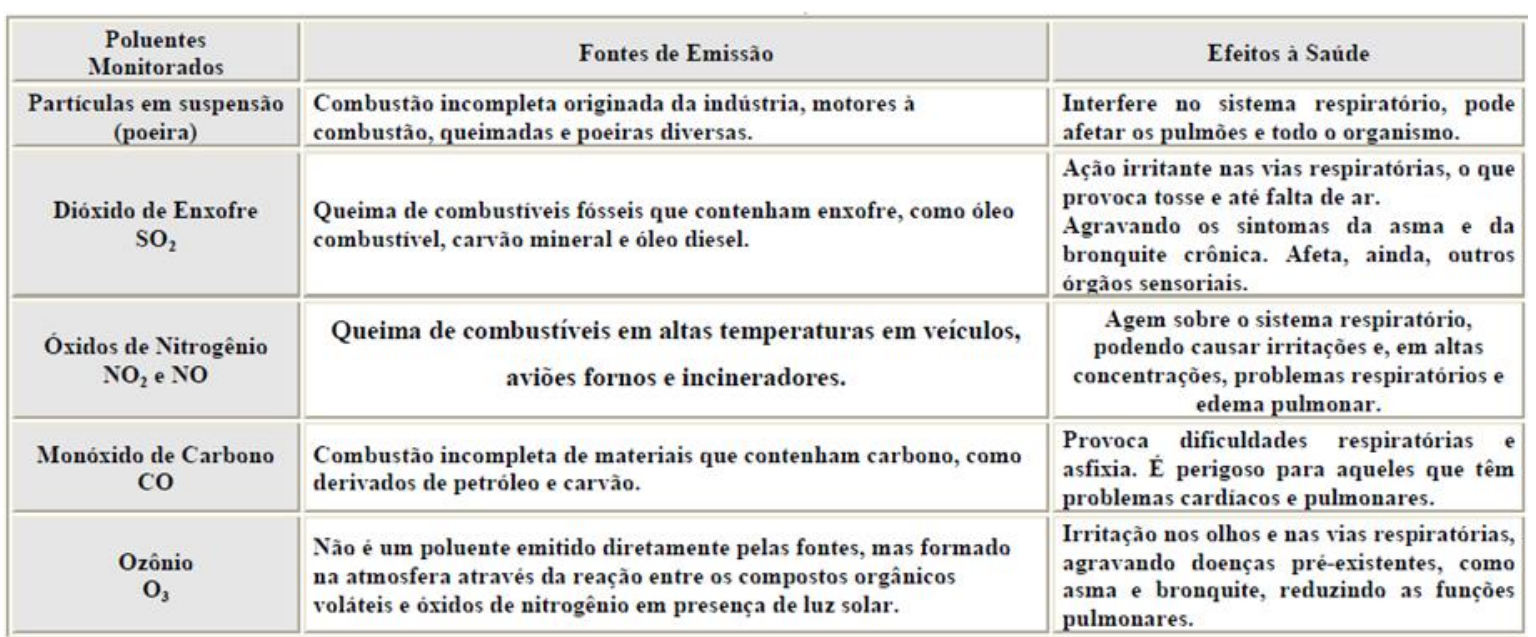

Figura 1: Principais Poluentes Urbanos, Fontes de Emissão e Efeitos a Saúde. Fonte: INEA (2009).

\section{MATERIAIS E MÉTODOS}

Para cumprir o objetivo deste estudo utilizou-se como base de dados as estações automáticas de monitoramento do INEA - Campos Elíseos, Pilar, Jardim Primavera, Vila São Luiz e São Bento. Além disso, procedeu-se com a análise, a partir da RAIS 2010 - Relatório Anual de Informações (Ministério do Trabalho), das atividades industriais do município, a base de dados de licenciamento da Prefeitura Municipal de Duque de Caxias (PMDC) entre 2013 e 2015 e a evolução do zoneamento industrial. Finalmente, dados da frota municipal foram obtidos no sítio eletrônico do Departamento Nacional de Transito (DENATRAN).

Para cumprir a primeira parte da análise, devido à má distribuição (concentração) espacial das estações, optou-se pela não utilização de técnicas geoestatísticas, mas sim, a utilização da matriz de dispersão para os dados horários, cujo objetivo é compreender a correlação entre as estações de monitoramento, analisada em conjunto com os dados de vento da estação REDUC, referindo-se as medições do ano de 2005 extraídas do EIA-RIMA (2007) apud Sodré et al. (2010).

A matriz de dispersão é um gráfico que permite avaliar a relação entre diversos pares de variáveis ao mesmo tempo. Já o boxplot, permite avaliar alguns aspectos da distribuição dos dados como a posição, variabilidade (em termos de intervalo de oscilação dos quantis), assimetria e ocorrência de valores atípicos na série (GALVANI; LUCHIARI, 2005), permitindo, portanto, a identificação de ocorrência de níveis intensos e extremos de PTS por estação de monitoramento para a área de estudo, levando em consideração ainda a distribuição da exposição à poluição atmosférica.

A identificação destas informações é possível, afinal o gráfico de boxplot é uma representação gráfica da estatística posicional dos quartis (HARDLE; SIMAR, 2012), que após o ordenamento das amostras são calculados o centro (mediana) e seus limites inferiores e superiores, tanto internos à caixa plot ( $1^{\circ}$ quartil $-25 \%$ da distribuição; $2^{\mathrm{a}}$ quartil $-50 \%$ da distribuição; $3^{\circ}$ quartil $-75 \%$ da distribuição) quanto externos, conhecidos como bigodes ou whiskers, e também a representação dos pontos discrepantes denominados de outliers. Adicionalmente, os dados horários foram transformados em médias diárias, nos quais se aplicou o teste de shapiro-wilk e constatou-se sua não normalidade, permitindo a seleção do método não paramétrico de Mann-Kendall para avaliação da tendência temporal das estações supracitadas no período em pauta.

\section{RESULTADOS E DISCUSSÃO}

Em 1980 foi promulgada a lei federal $n^{\circ} 6.803$ que visava a compatibilização da atividade industrial com a proteção ambiental, oferecendo novas questões de ordem jurídica para zoneamento urbano, evitando conflitos de uso, sobretudo com as zonas residenciais da malha urbana. Em Duque de Caxias, os instrumentos legais destinados ao zoneamento industrial iniciam-se em 1971, não coincidentemente referindo-se à refinaria recém instalada. 
Em 1972 é aprovado o primeiro plano diretor do município que em 1973 vira decreto (decreto $\mathrm{n}^{\circ} 841$ de 14 de novembro de 1973), o qual sofreria sucessivas modificações até abril de 2006. Vale dar atenção dentre essas modificações à definição de uma faixa de 600 metros no entorno das rodovias (BR040 e BR116) para qual o uso industrial, de qualquer tipo, seria conforme.

Os decretos, que ao longo de mais de 3 décadas ampliaram significativamente a área destinada à atividade industrial, refletiam a crença e opção tomada na época quanto ao potencial industrial desse município (haja vista o símbolo da bandeira do município figurar uma indústria, que inclusive está expelindo seus poluentes), muito justificada pelos eixos rodoviários ali presentes.

O reflexo da legislação urbanística até abril de 2006 encontra-se na Figura 2, em que é possível observar a abrangência espacial das áreas destinadas à atividade industrial, representando quase $27 \%$ do território municipal ${ }^{3}$. Os setores mais graves do ponto de vista do conflito de uso são aqueles localizados as margens das rodovias, que em grande parte eram, de acordo com o primeiro plano diretor, destinadas ao uso habitacional e misto e posteriormente passaram a admitir a conformidade do uso industrial.

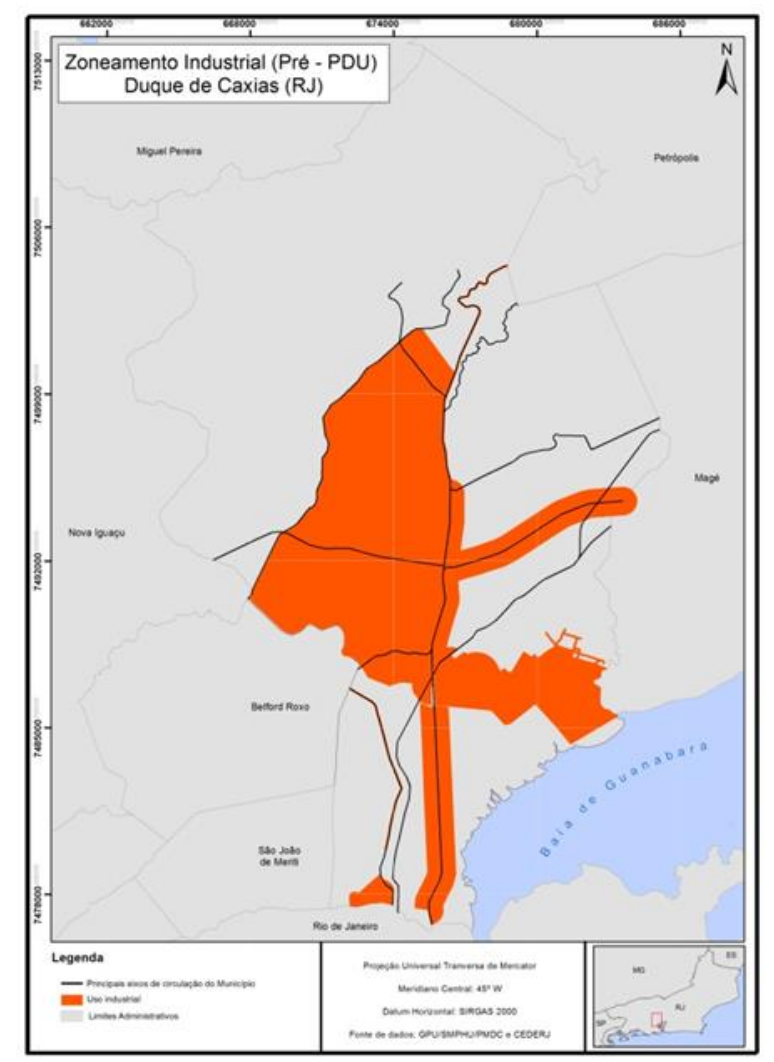

Figura 2: Zoneamento Industrial anterior a 2006. Fonte de dados: PMDC.

Já o plano diretor urbanístico aprovado em outubro de 2006 (Figura 3) reverte significativamente as parcelas do território destinadas às atividades industriais, uma diminuição de $275 \%$, oferecendo um novo tom ao ordenamento territorial local, a priori mais coerente com a proposta da lei federal $\mathrm{n}^{\circ} 6.803$, em que segregam as zonas estritamente industriais (Campos Elíseos) e predominantemente industriais (Figueira), além de outras destinadas a temas específicos como a logística (Centro Atacadista, Estrela e Meriti), setor com grande destaque no município.

\footnotetext{
${ }^{3}$ Ao analisarmos esse valor devemos lembrar que extensas áreas ao norte do município encontram-se sob o domínio das escarpas da Serra dos Órgãos, com restrições à ocupação, reduzindo, portanto a área "útil” do território municipal. 


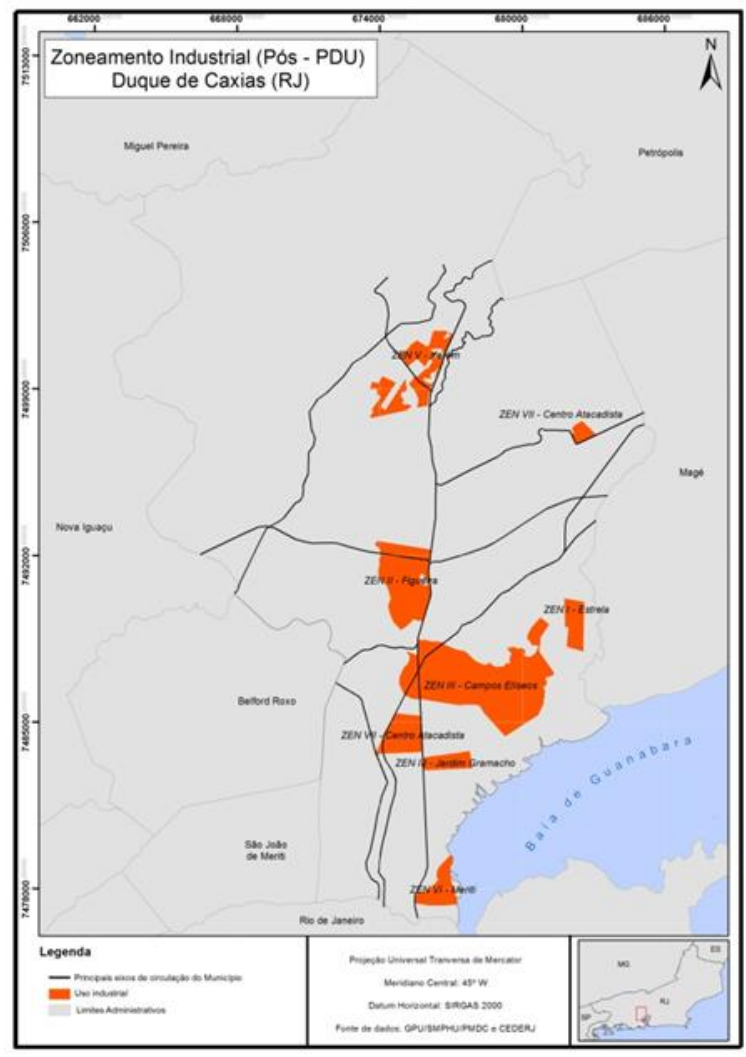

Figura 3: Zoneamento Industrial posterior a 2006. Fonte de dados: PMDC

No entanto, deve-se destacar que o macrozoneamento apresentado no novo plano diretor pouco intervém na política de ordenamento territorial do município, isso porque as leis complementares que deveriam ter sido elaboradas sequer ganharam versão de minuta, dificultando significativamente a gestão e planejamento urbano. Dada essa ausência, os setores técnicos continuam utilizando o zoneamento e parâmetros urbanísticos de legislações anteriores ao plano de outubro de 2006.

Em suma, apesar da existência de diretrizes no plano diretor urbanístico, em consonância aos preceitos sociais, democráticos e participativos estabelecido pelo Estatuto das Cidades (lei federal $\mathrm{n}^{\circ} 10.257$, de 10 de julho de 2001), o ordenamento territorial duquecaxiense praticado ainda é reflexo de uma legislação amplamente permissiva ao uso industrial, favorecendo a exposição da população a gases nocivos à saúde.

Como reflexo desse quadro normativo, observa-se, através de dados de 2010, no município um significativo espraiamento das atividades industrial (Figura 4), sobretudo da indústria química (com 157 unidades), uma realidade muito mais coerente com o zoneamento da Figura 2 do que da Figura 3. A análise conjunta dos dados industriais e da densidade demográfica municipal corrobora o argumento acerca da ocorrência de conflitos de uso no município que expõem a população aos riscos tecnológicos, uma vez que as áreas com densidade industrial são, em muitas das vezes áreas densamente povoadas, sobretudo ao sul, o primeiro distrito.

A análise das Figuras 4 e 5 destacam também a importância dos eixos rodoviários e ferroviário na conformação da malha urbana municipal. Tanto a localização das indústrias, quanto a aglomeração da população ocorre direcionado por estes eixos de circulação, de forma que é possível afirmar que tais conflitos de uso se referem a um passivo histórico da ocupação do território, em que pesam significativamente às decisões legislativas, e, sobretudo do executivo municipal. Este último merece atenção visto que a grande maioria das legislações urbanísticas municipais foram sancionadas via decretos e não leis, demasiadamente questionável do ponto de vista jurídico. 


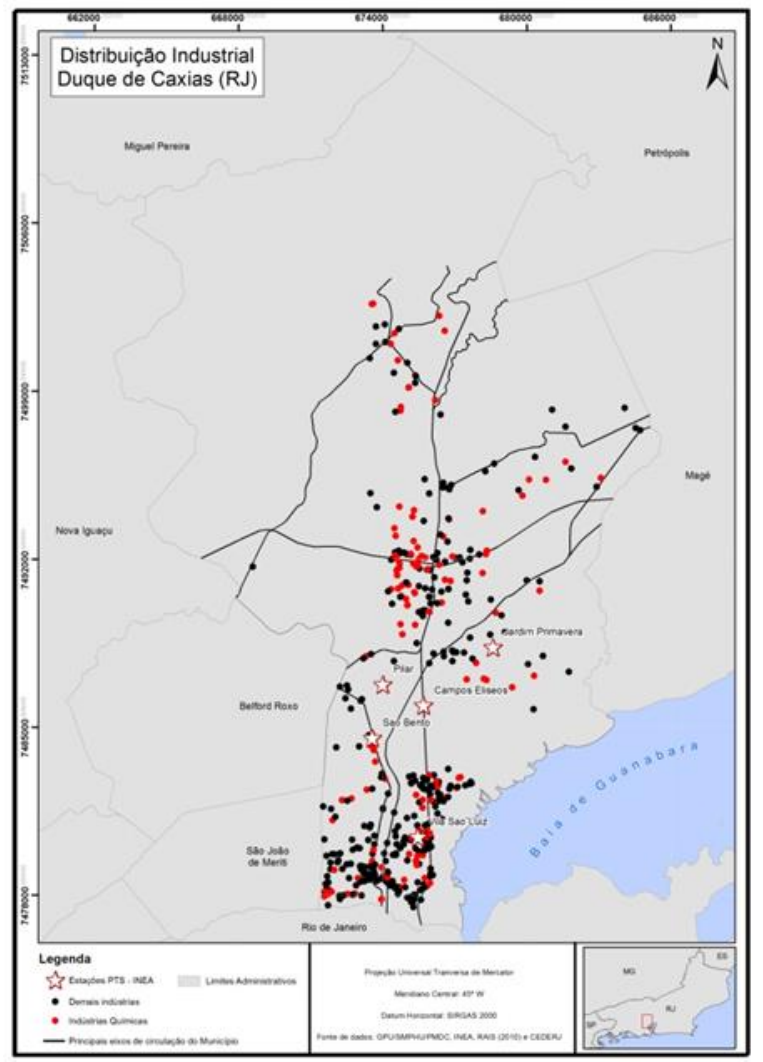

Figura 4: Localização das indústrias no território municipal. Fonte de dados: RAIS 2010

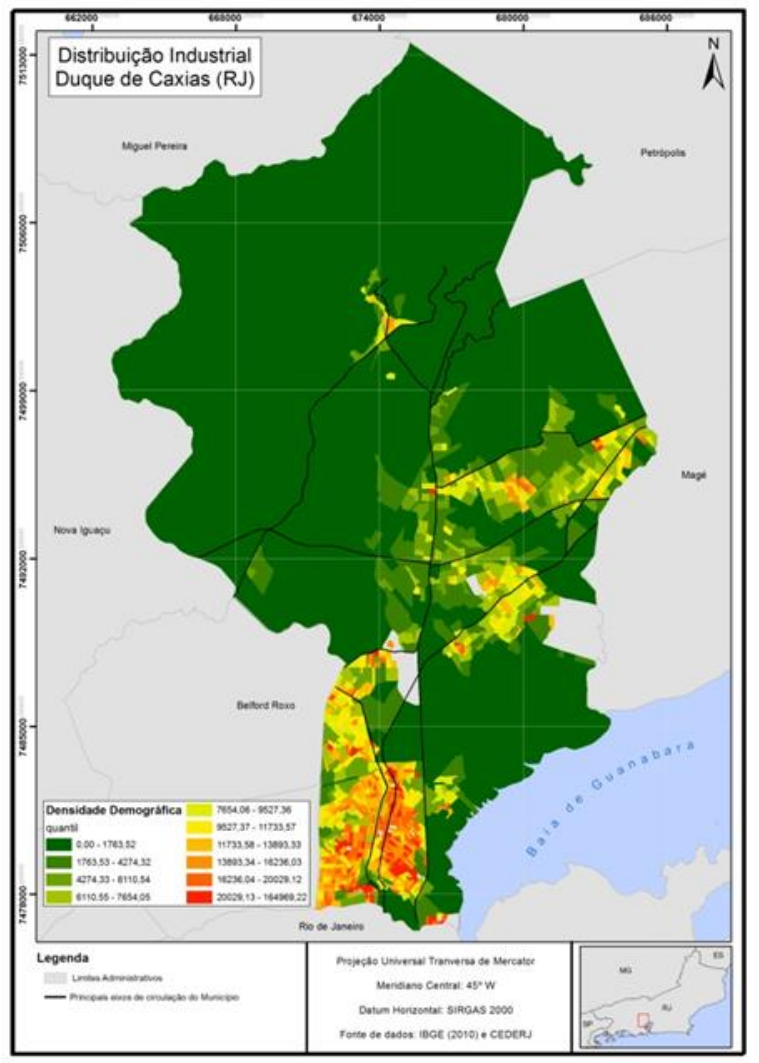

Figura 5: Densidade demográfica. Fonte de dados: IBGE (2010). 
Atualmente, a abertura do Arco Metropolitano no município inicia uma nova fase de atividades econômicas, reverberando-se no expressivo aumento de atividades logísticas em Duque de Caxias - galpões (Gráfico 1), materializado o potencial identificado no plano diretor urbanístico de 2006. Entre 2013 e 2014 foram mais de 50 processos de licenciamento edilício de galpões no município, no entanto, nesse valor a que considerar as construções irregulares, comuns no município, e que vem ocorrendo, sobretudo próximas do arco metropolitano, segundo informações do setor de fiscalização da Subsecretaria de Urbanismo.

Gráfico 1: Comparativo anual dos processos de licenciamento edilícios em Duque de Caxias (2013, 2014 e 2015). Fonte: Gerência de Licenciamento Urbano, SMPHU - PMDC.

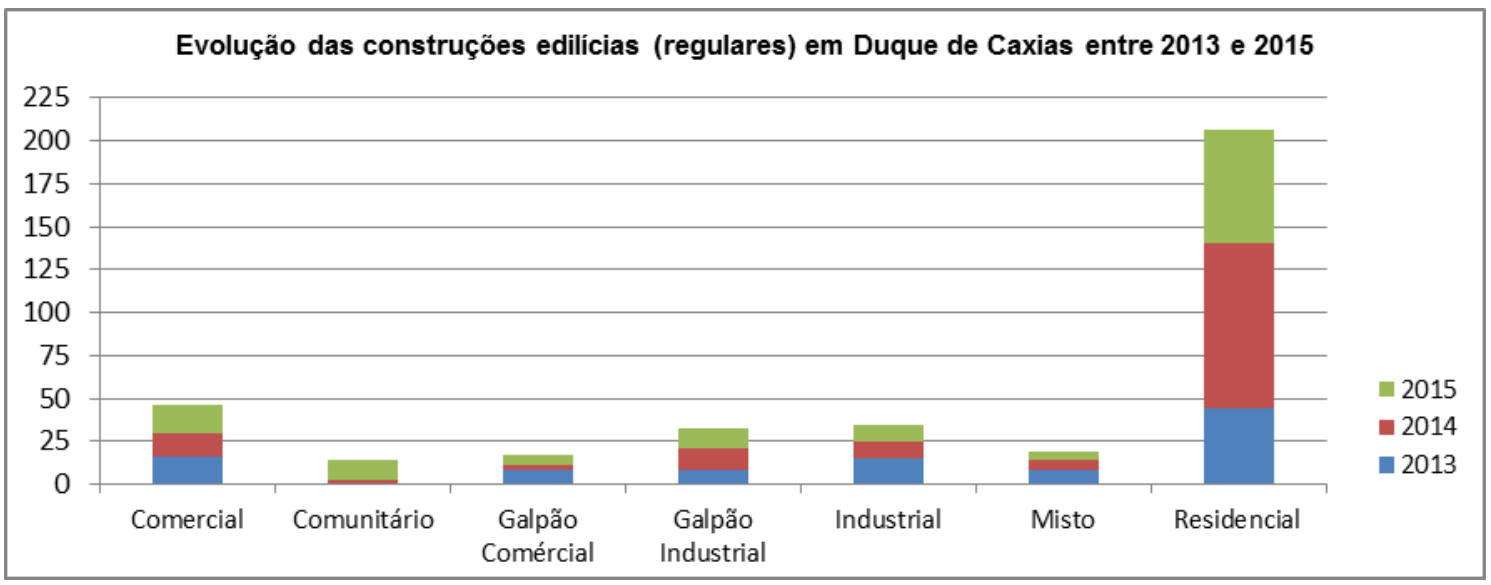

Fonte: Rosgen (1994)

O reflexo da expansão do setor de logística no município provoca impactos diretos na qualidade do ar local em virtude da maior circulação de caminhões no município. Dados sobre a frota veicular municipal apontam para um aumento de 78\% dos caminhões, entre 2001 e junho de 2016, registrados para Duque de Caxias. A pujança logística do município pode ser observada também nos dados de fluxo de veículos que segundo dados da CONCER (2015) são de: 19.000 veículos por dia no sentido Rio de Janeiro - Belo Horizonte e 17.000 no sentido Belo Horizonte - Rio de Janeiro para o Km 104 (pedágio); e, 72.000 veículos por dia no sentido Rio de Janeiro - Belo Horizonte e 60.000 no sentido Belo Horizonte - Rio de Janeiro para o km 112 (Campos Elíseos).

A partir dos dados acima, é possível observar, primeiro que os dados da frota de caminhões para o município, provavelmente são subestimados, visto que os empreendimentos logísticos fazem parte de grandes cadeias logísticas com o trânsito de caminhões extramunicipais e extraestaduais, dificulta seu real dimensionamento. Além disso, que 71,7\% dos veículos do sentido Belo Horizonte - Rio de Janeiro e 73,6\% dos veículos do sentido Rio de Janeiro - Belo Horizonte ficam no território duquecaxiense, indicando a atratividade desse município. Tais dados são fundamentais, visto que $70 \%$ das emissões atmosféricas são oriundas de fontes moveis (INEA, 2009).

Retomando a distribuição de indústrias no município, quando analisadas em relação às estações de monitoramento da qualidade do ar, é acertado concluir que apenas 4 estações não são suficientes para tal práxis, carecendo de pelo menos mais 2 estações ao norte. Inicia-se, portanto essa analise suscitando um dos limitadores dessa análise, ao qual se soma também a carência de dados de vento, fundamentais a analises mais substanciais.

Tomando como referência os dados horários convertidos para médias diárias, quando submetidos ao teste de Shapiro-Wilk apresentaram resultados favorável para a hipótese nula, ou seja, os dados das cinco estações de qualidade do ar em estudo não correspondem a uma distribuição normal. Em face disto, optou-se pela utilização do teste não paramétrico de Mann-Kendall para avaliação da tendência e significância para o período entre 2004 e 2009 (e para o caso da estação Vila São Luiz entre 2006 e 2009). Segundo a Organização Meteorológica Mundial (OMM), este é o teste mais recomendado para verificação de tendências em séries climatológicas, por isso, a decisão de aplica-lo também em dados de material particulado, dado sua robustez.

A partir das análises de Mann-Kendall constatou-se para o período uma tendência negativa para as estações Campos Elíseos $(-0.0074 \mu \mathrm{g} / \mathrm{m} 3 / \mathrm{dia})$, São Bento $(-0.0153 \mu \mathrm{g} / \mathrm{m} 3 /$ dia $)$ e Vila São Luiz $(-0.0048$ $\mu \mathrm{g} / \mathrm{m} 3 /$ dia $)$. Já para as estações Pilar $(0.0015 \mu \mathrm{g} / \mathrm{m} 3 /$ dia $)$ e Jardim Primavera $(0.0071 \mu \mathrm{g} / \mathrm{m} 3 /$ dia $)$ esta tendência foi positiva. 
Partindo para as análises horárias, há de destacar que os eventos mais significativos de concentração de PTS para o período estudado ocorreram para as estações Pilar $(859,7 \mu \mathrm{g} / \mathrm{m} 3)$ e São Bento $(823,17 \mu \mathrm{g} / \mathrm{m} 3)$, ambos em agosto de 2009. No entanto, em termos de variabilidade, é fundamental a análise dos Boxplots ${ }^{4}$ mensais de cada estação de monitoramento (Figuras 6 e 7).

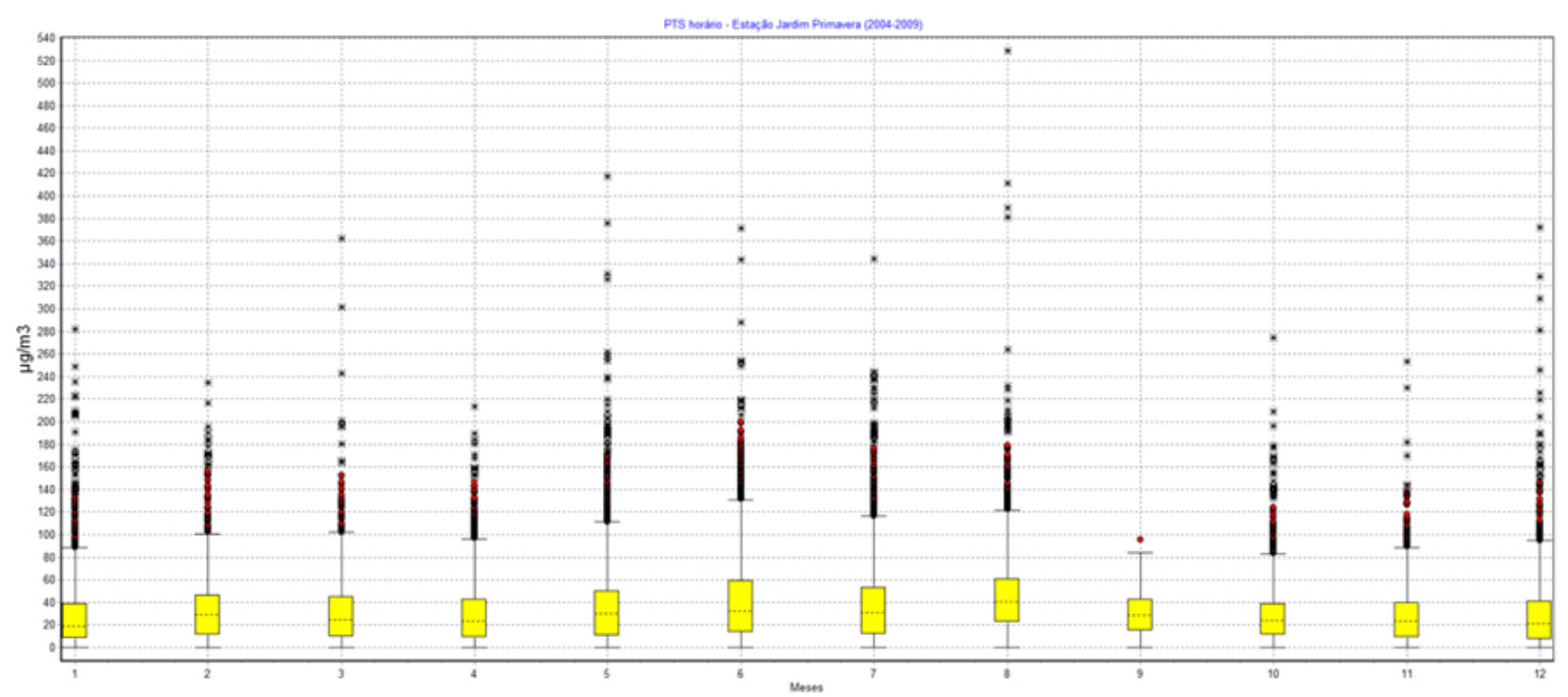

Figura 6: Distribuição mensal do PTS para a estação Jardim Primavera pelo método Boxplot. Fonte de dados: INEA

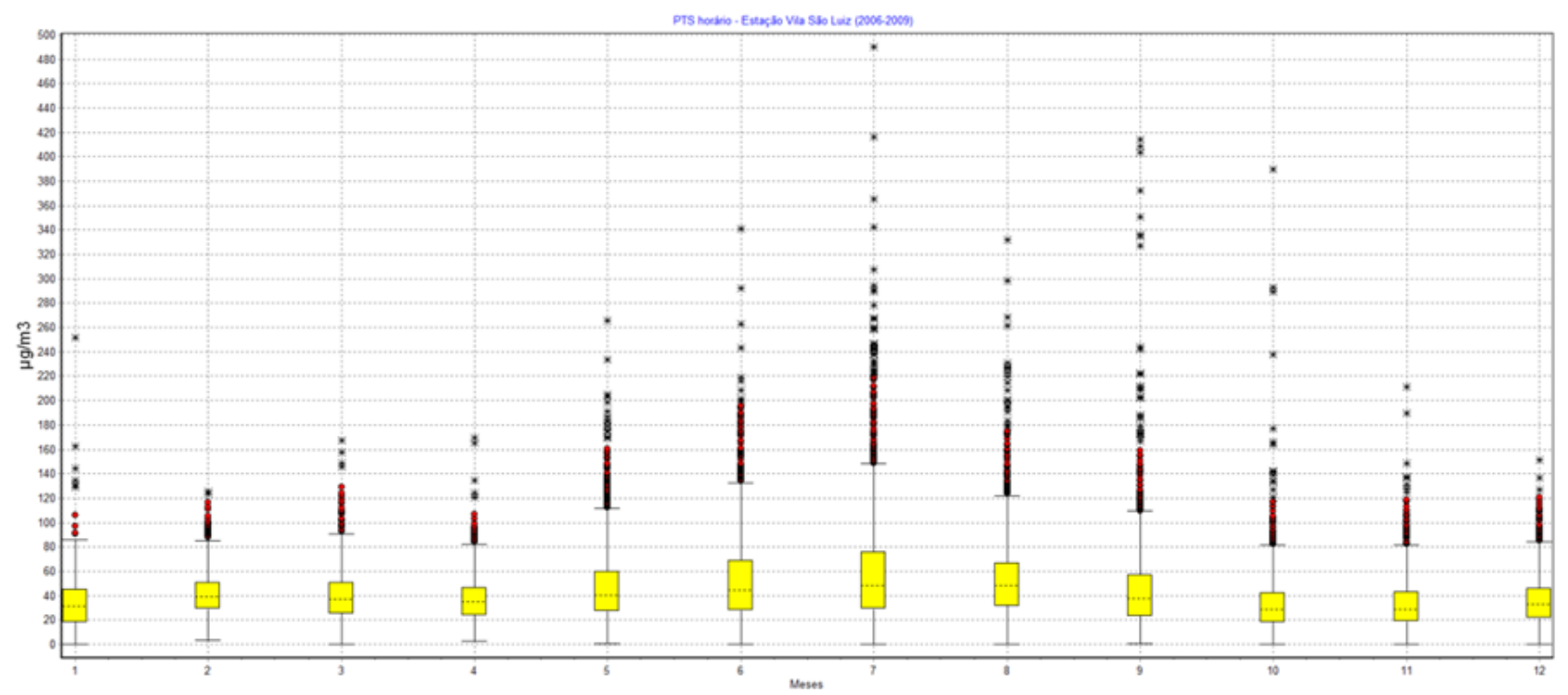

Figura 7: Distribuição mensal do PTS para a estação Vila São Luiz pelo método Boxplot. Fonte de dados: INEA

Os dados da estação Jardim Primavera ( $2^{\circ}$ distrito) apontam para um desvio interquartílico superior nos meses de inverno, acompanhado por uma maior altura dos wiskers e intensidade dos outliers. Estas informações sugerem para esses meses, sobretudo junho e agosto, aumento do particulado atmosférico, levando a crer na piora da qualidade do ar. Inversamente, o mês de setembro refere-se ao mês de emissões atmosféricas menos intensas para a série.

\footnotetext{
${ }^{4}$ Devido o limite de páginas optou-se pela apresentação dos gráficos da estação Vila São Luiz, que além da tendência negativa é o único localizado no primeiro distrito do município e da estação Jardim Primavera, com a tendência positiva mais significativa.
} 
Já para a estação Vila São Luiz, além de uma melhor simetria da caixa plot, expressando uma distribuição mais próxima do normal, observa-se também que no mês de julho há significativo aumento particulado atmosférico para o primeiro distrito, mesmo resultado encontrado por Gallego (1972) para o Rio de Janeiro, indicando uma coerência espacial do resultado em virtude da maior proximidade deste distrito à área industrial da cidade do Rio de Janeiro. O maior distanciamento dos wiskers nesta estação sugere uma maior variabilidade no particulado no período de outono e inverno. Além disso, os outliers, mais significativos na estação Jardim Primavera que Vila São Luiz, dão indícios do perfil da qualidade do ar do município, cuja frequência é maior a partir final da tarde e noite.

Os resultados encontrados na análise dos boxplot corroboram os resultados encontrados por Gallego (1972) para a cidade do Rio de Janeiro (RJ), Braga et al. (2007) para Itabira (MG), Alves et al. (2015) para Monteiro (PB) indicando o período de outono e inverno, sobretudo o período entre maio e setembro, como os de atenção em termos de poluição atmosférica. Gallego (1972) explica isso para o caso carioca, em virtude da maior atuação da Massa Tropical Atlântica.

Em relação aos resultados obtidos através da matriz de dispersão ${ }^{5}$, observa-se no ano de 2004 uma correlação positiva entre todas as 04 estações de monitoramento analisadas, possivelmente explicados pelos ventos predominantes de sudeste, porém mais significativa entre Campos Elíseos e Pilar, o que não ocorre para o ano de 2005, cuja correlação entre ambas é negativa. Nesse ano, há uma correlação positiva mais acentuada entre as estações Campos Elíseos e Jardim Primavera, Jardim Primavera e Pilar e São bento e Jardim Primavera.

A partir de 2006 a estação Vila São Luiz começa a ser incorporada na análise, no entanto, observa-se uma correlação negativa desta com as demais estações de monitoramento em quase todo período, e viceversa, exceto em 2009, quando há correlação positiva entre Campos Elíseos e Vila São Luiz. Retornando ao ano de 2006, é possível constatar correlações positivas significativas entre Pilar e Campos Elíseos, bem como Pilar e São Bento.

Em 2007, observa-se correlação positiva mais significativa entre Campos Elíseos e Pilar e Campos Elíseos e São Bento, ambos possivelmente favorecidos pelos ventos de sudeste. Há que se destacar ainda a correlação positiva entre São Bento e Pilar. Em 2008 (Figura 8), mais uma vez Campos Elíseos apresenta correlação positiva com todas as demais estações (exceto Vila São Luiz), com destaque aquela mais significativa entre Campos Elíseos e Jardim Primavera e Campos Elíseos e São Bento. Mais uma vez há correlação positiva entre Campos Elíseos e Pilar, Jardim Primavera e Pilar e Pilar e São Bento. Finalmente, em 2009 (Figura 9), observa-se uma correlação positiva entre a estação Campos Elíseos e as demais, incluindo desta vez a estação Vila São Luiz, que neste ano apresenta a correlação positiva mais significativa. Outro ponto que merece ser destacado, é que apesar das estações São Bento e Pilar apresentarem, no mês de agosto de 2009, os maiores picos de PTS da série: 823,17 $\mu \mathrm{g} / \mathrm{m} 3$ (02/08/2009) e 859,7 $\mu \mathrm{g} / \mathrm{m} 3$ (19/08/2009) respectivamente.

A explicação para tais resultados pode ocorrer em função dos ventos locais, com predominância dos ventos de sudeste estabelecendo uma possível dissipação do particulado da estação Campos Elíseos para as demais (exceto Vila São Luiz). Os ventos de noroeste, nordeste e sudoeste também destacam-se em segundo plano na área de estudo, subsidiando as correlação do tipo: Pilar-São Bento; Jardim Primavera-Pilar; São Bento-Pilar, São Bento-Jardim Primavera.

\footnotetext{
${ }^{5}$ Novamente em virtude da limitação de páginas optou-se pela exemplificação através dos anos de 2008 e 2009 , os mais recentes da série.
} 


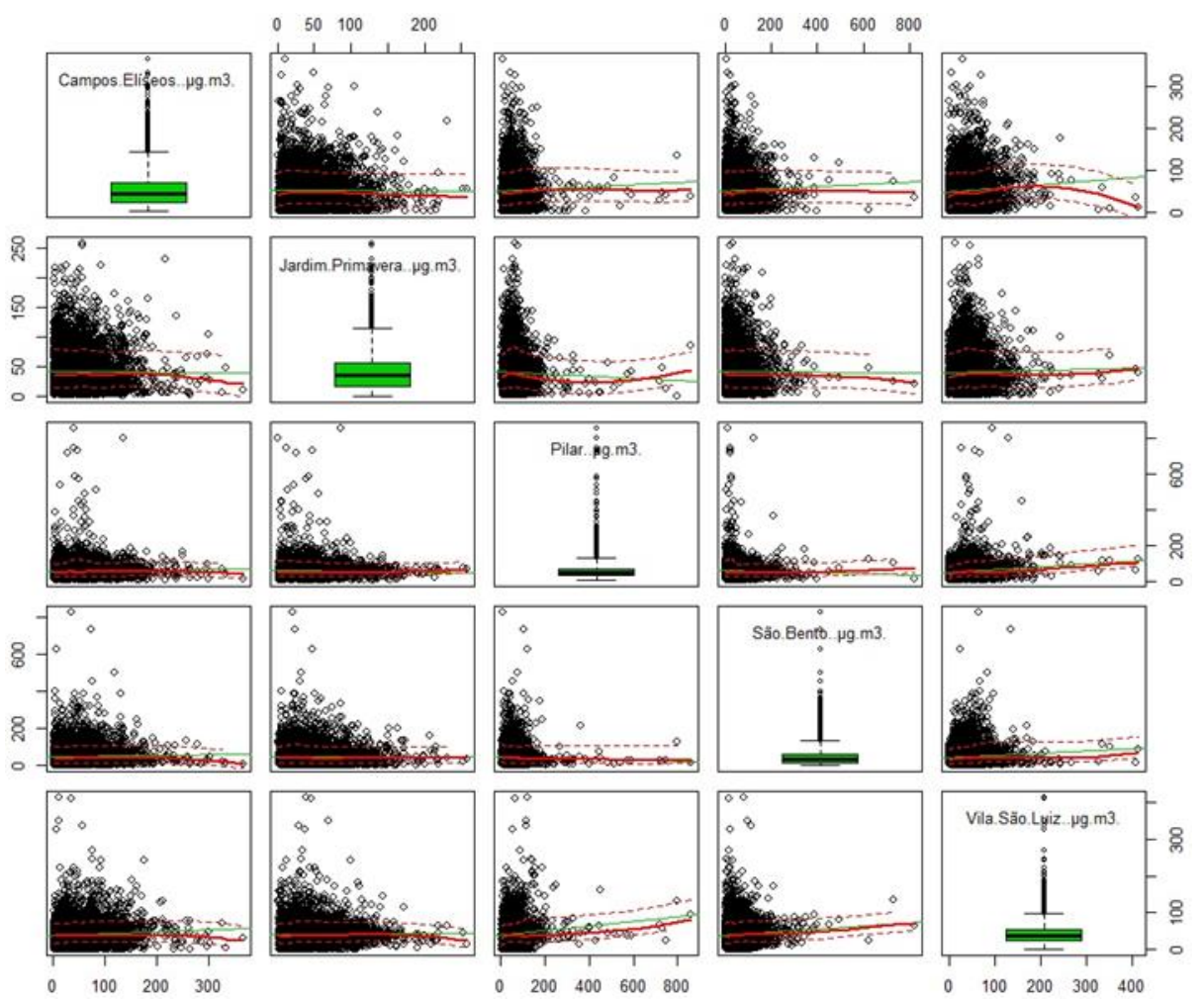

Figura 8: Matriz de dispersão dos dados horários das estações de monitoramento em Duque de Caxias no ano de 2008. Fonte de dados: INEA.

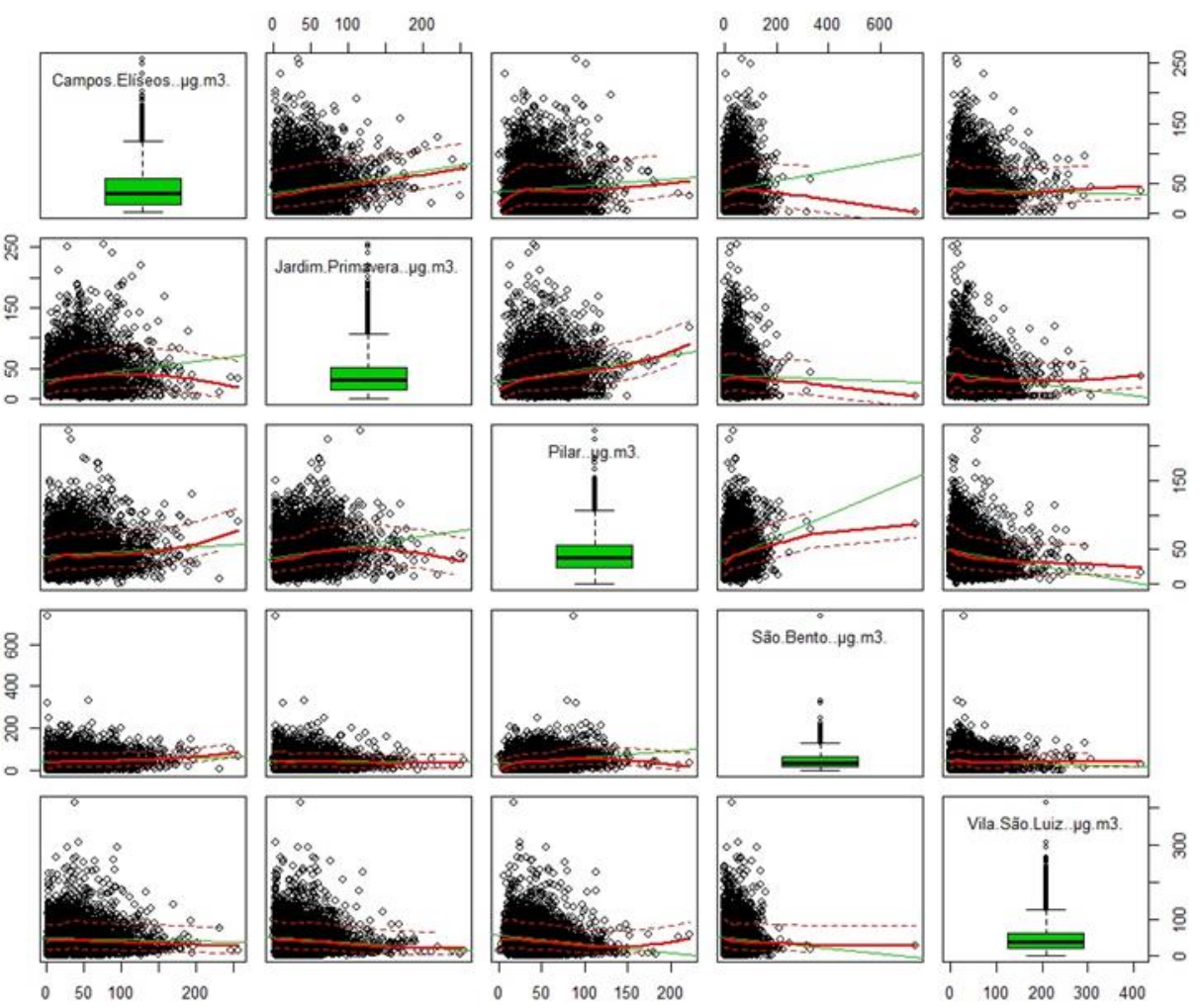

Figura 9: Matriz de dispersão dos dados horários das estações de monitoramento em Duque de Caxias no ano de 2009. Fonte de dados: INEA. 
Dada tais características, a hipótese mais provável em termos de ocorrência, é que o material particulado posto em suspensão nas proximidades da estação Campos Elíseos é dissipado pelos ventos de sudeste (Figura 10) em direção à Xerém, repercutindo, sobretudo na qualidade de ar das estações vizinhas ao parque industrial e que encontram no quadro topográfico (Figura 11), último argumento para tal fundamentação, com ocorrência de morrotes elevados, obstáculos para a dissipação do particulado. Em segundo plano, Pilar, através dos ventos de sudoeste e Jardim Primavera através dos ventos de noroeste (ambos os ventos com menor frequência) explicariam o padrão espacial de suspensão do material particulado (também influenciado pelo relevo).

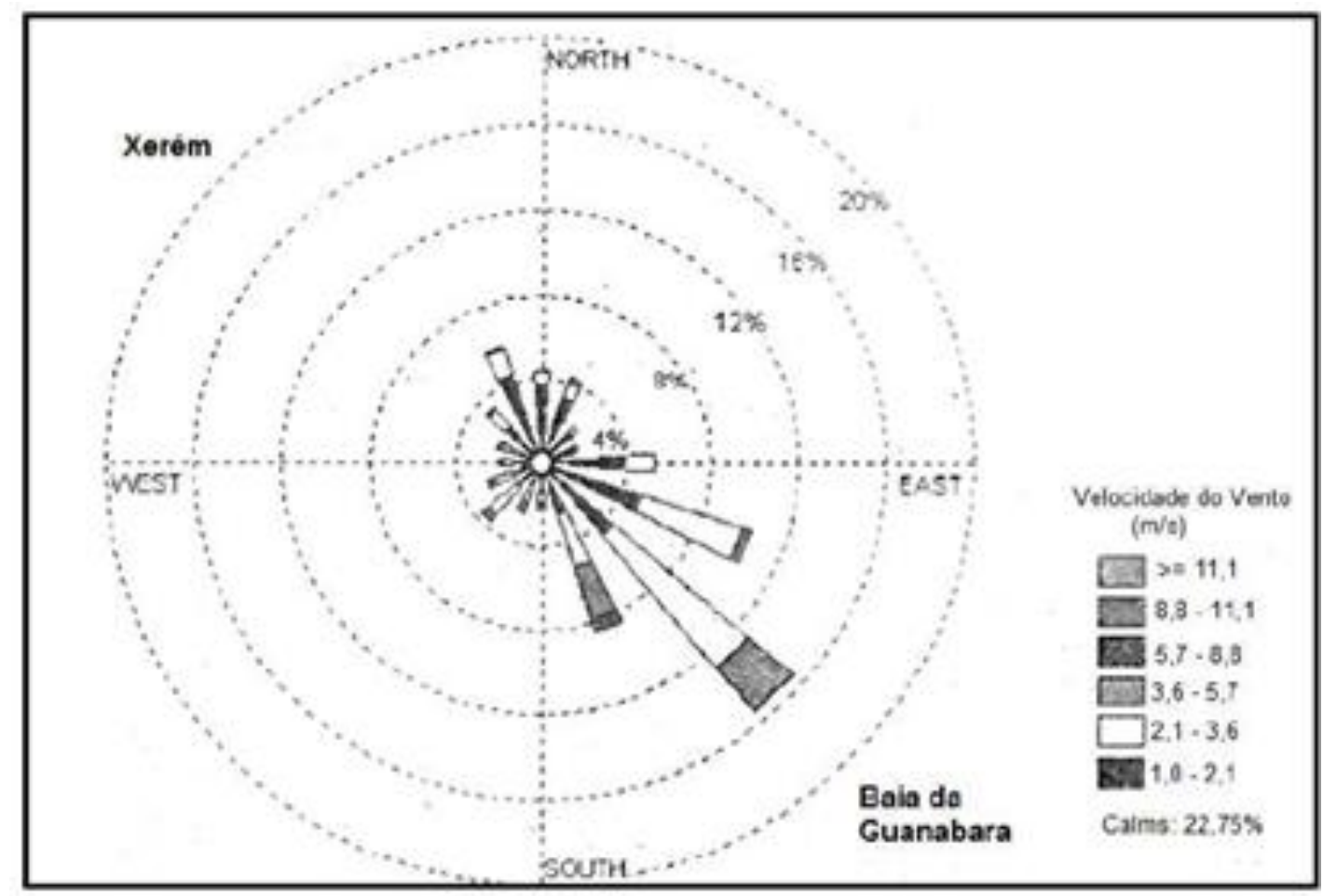

Figura 10: Gráfico tipo Rosa dos Ventos na estação REDUC, período completo do ano de referência 2005. Fonte: EIA/RIMA PETROBRAS (2007) apud Sodré et al. (2010).

Nesse sentido, é possível crer que a estação de Campos Elíseos é a principal fonte do particulado ${ }^{6}$ no município, face às significativas correlações positivas encontradas e mencionadas quando da análise dos dados de dispersão. Já a localização da estação Vila São Luiz e o padrão de ventos locais explicam a não correlação entre Campos Elíseos e Vila São Luiz (exceto para 2009, que precisaria de uma análise barométrica mais detalhada para melhor entendimento da correlação).

Em virtude da relevância dos ventos de sudeste para o município, o crescente processo de verticalização que ocorre no litoral duquecaxiense (Figura 12) é um dos novos desafios do planejamento urbano, visto que o bloqueio destes ventos, exercido pelas construções, pode alterar significativamente o padrão de circulação e dispersão apresentados, culminando em novas estratégias de mitigação da problemática, bem como, novas perspectivas para as políticas de ordenamento da cidade.

\footnotetext{
${ }^{6}$ É valido explicitar que quando se faz referencia às Campos Elíseos, não há elementos suficientes para creditar à refinaria esse particulado, mas sim a rede industrial estabelecida, a qual, indubitavelmente, foi desenvolvida em função de sua presença.
} 


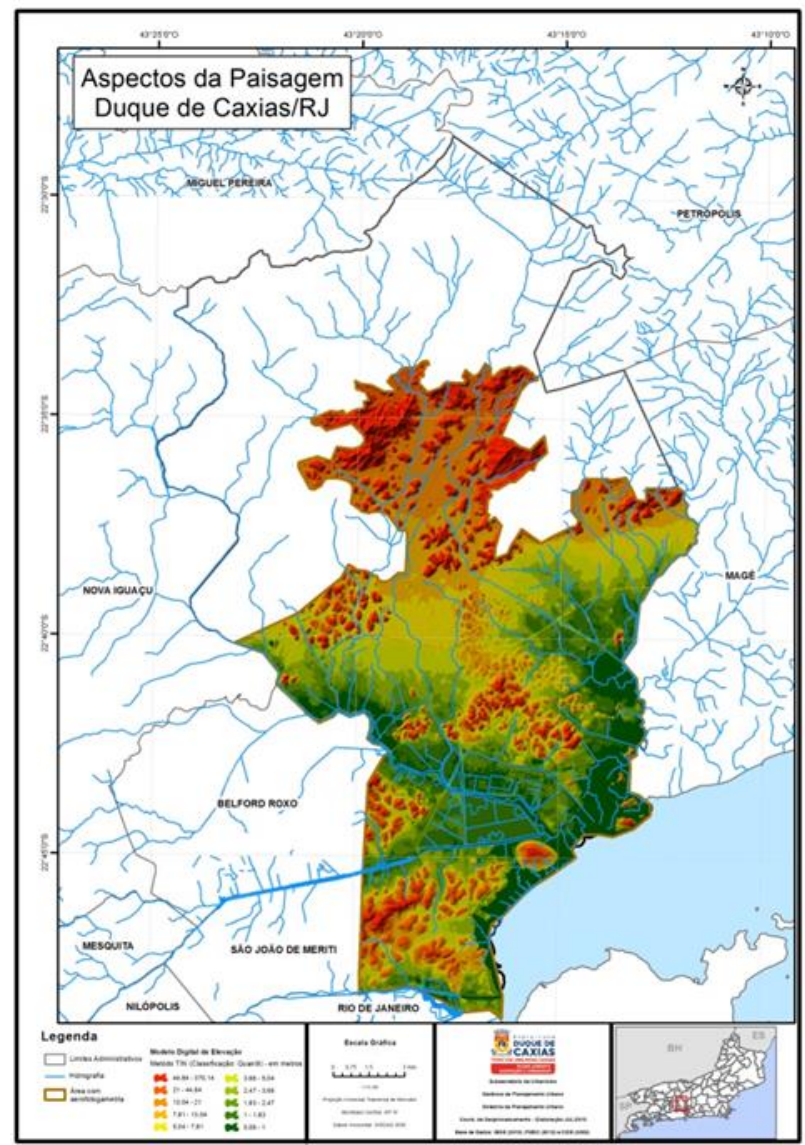

Figura 11: Topografia do município de Duque de Caxias. Fonte: Gerência de Planejamento Urbano, SMPHU/PMDC.

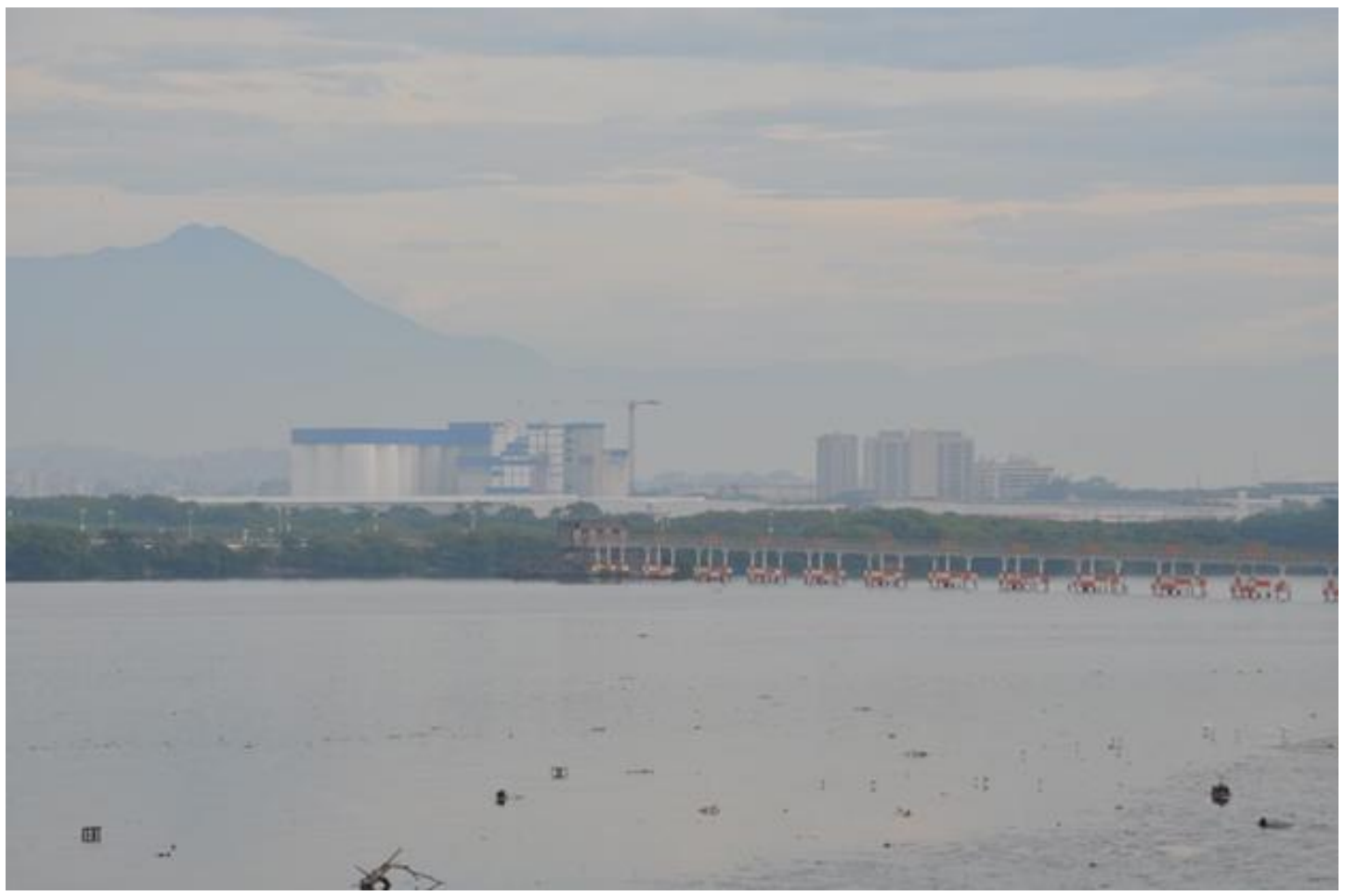

Figura 12: Comportamento edilício no litoral da Baia de Guanabara, $1^{\circ}$ distrito de Duque de Caxias em maio de 2016. Foto: Marcio Wixak Vieira da Motta. 


\section{CONCLUSÕES}

Atualmente, em virtude da necessidade elencada de adaptação e mitigação à Mudança Climática, emerge na agenda urbana novos paradigmas urbanísticos (BULKELEY et al., 2003), orientados para a mistura e compactação de usos, otimização do uso do transporte, com ênfase naqueles menos poluentes ou de alta capacidade. De certo, trata-se de ações de custo positivo, afinal, caso os impactos previstos não sejam observados, os benefícios obtidos por essas práticas reverberarão positivamente na mitigação da poluição atmosférica.

Segundo Gallego (1972) "a escolha de áreas para implantação das zonas industriais e urbanas, eixos de circulação e a criação de espaços verdes devem completar, ou melhor, preceder as resoluções técnicas de prevenção". Nesse sentido, a lei federal $\mathrm{n}^{\circ} .6 .803$ de 1980 ofeceu uma base normativa para tal intervenção, no entanto o que se observa em nível são ações do ente municipal, detentor da incubência do parcelamento e uso do solo, que sobrepõe os interesses econônomicos aos da população.

Cabe, portanto nas discussões acerca do Clima Urbano coadunar às considerações sobre a Geografia do Clima, visto que o trato dado ao territorio pelos diversos agentes economicos repercute diretamente nos três canais de percepção aventados por Monteiro (1976), sobretudo, conforme demonstrado, para o canal físico-químico. Ainda nessa discussão, observa-se que o poder público, que por exelencia é o intermediador dos conflitos e sobre quem deveria recair a imparcialidade não trabalha nessa linha. Portanto, as políticas públicas duquecaxiense são interessadas, favorecendo o agravemeto do problema em pauta e reafirmando o papel das políticas públicas nas práticas espaciais.

Do ponto de vista climatológico, alguns elementos devem ser considerados: a ausência de uma base dados maior e mais detalhada de ventos; a própria concentração espacial das estações de monitoramento; detalhamento dos poluentes em suspensão. No entanto, mesmo assim, os resultados foram satisfatórios, demonstrando um padrão de variabilidade anual, mais crítico no período de inverno, sobretudo entre junho e agosto, no final da tarde e a noite (período em que mais pessoas estão em casa e, portanto expostas à poluição), bem como um padrão de dispersão predominante de sudoeste, fazendo com que para o período de 2004 a 2009, houvesse seguidas correlações positivas da estação Campos Elíseos com as demais.

Em virtude dos resultados encontrados, e ainda com base nas modelagens feitas por Gregório (2011) a partir do modelo CATT-BRAMS, é urgente a necessidade de instalação de novas estações de monitoramento da qualidade do ar a norte do município, afinal constatou-se que os poluentes tendem a seguir essa trajetória em direção ao quarto e terceiro distrito. Já à municipalidade, cumpre rever sua legislação urbanística dando maior rigor aos parâmetros e a localização das atividades industriais, sobretudo: à indústria química, atualmente espalhada em todo território municipal; à logística em função do incremento no transito de veículos; bem como no processo de verticalização do litoral que promoverá alterações no padrão de circulação local.

\section{AGRADECIMENTOS}

O autor agradece à ABCima e RDG-USP pelo convite para participar dessa edição que homenageia o grande expoente da Geografia brasileira, Prof. Carlos Augusto Figueiredo Monteiro, bem como ao INEA por disponibilizar os dados de qualidade do ar, tornando factível esta análise e, finalmente, à prefeitura de Duque de Caxias na qual o autor cumpriu a função de Diretor de Planejamento Urbano e busca agora contribuir cientificamente para um melhor planejamento territorial desse Município com inúmeras potencialidades.

\section{REFERENCIAS}

ALVES, T. L. B.; AZEVEDO, J. V. V.; SANTOS, C. A. C.; AZEVEDO, P. V. Influência das variações climáticas na ocorrência de doenças das vias aéreas superiores no município de Monteiro - PB. Revista Ciência e Natura, Santa Maria, v.37, 4 set-dez. 2015, p.: 433-450.

BATALlER, M. A. S. El estudio de la gentrificación. Revista Bibliográfica de Geografía y Ciencias Sociales, Universidad de Barcelona, $\mathrm{n}^{\circ}$ 228, 2000. Disponível em: < http://www.ub.edu/geocrit/b3w228.htm> acesso em 10/07/2016.

BRAGA, A. L. F; PEREIRA, L. A. A.; PROCÓPIO, M.; ANDRÉ, P. A.; SALDIVA, P. H. N. Associação entre poluição atmosférica e doenças respiratórias e cardiovasculares na cidade de Itabira, Minas Gerais, Brasil. Cadernos de Saúde Pública, vol. 23, suppl.4, Rio de Janeiro, S570-S5782, 2007. 
BULKELEY, H.; BETSILL, M. M. Cities and Climate Change: urban sustainability and global environmental governance. Routledge: Londres, 2003.

CANÇADO, J. D. D. et al. Repercussões clínicas da exposição à poluição atmosférica. Jornal Brasileiro de Pneumologia. São Paulo, v.32, suppl.2, p. S5-S11, 2006.

CORRÊA. R. L. O espaço urbano. Ed. Ática: Rio de Janeiro, 1989.

DEVLIN, R.B.; GHIO, A.J.; KEHRL, H.; SANDERS, G.; CASCIO, W. Elderly humans exposed to concentrated air pollution particles have decreased heart rate variability. Eur Respir J Suppl 40, 2003, p.p.:76-80.

GALLEGO, L. P. Uma contribuição ao clima urbano do Rio de Janeiro: Tipos de tempo e poluição atmosférica nos anos de 1968-1969. Tese de doutorado: Universidade de São Paulo, Faculdade de Filosofia, letras e Ciências Humanas. 1972.

GALVANI, E; LUCHIARI, A. Critérios para a Classificação de Anos com Regimes Pluviométricos normal, seco e úmido. Anais do X Encontro de Geógrafos da América Latina. Universidade de São Paulo. 57015710,2005

GREGÓRIO, L. S. Risco ambiental à saúde humana: Um Estudo Aplicado aos Efeitos da Poluição Atmosférica no Estado do Rio de Janeiro. Dissertação de Mestrado. Rio de Janeiro: Programa de Pós Graduação em Geografia - UFRJ. 2011, 153 p.

HARDLE, W. K; SIMAR, L. Applied Multivariate Statistical Analysis, 3rd ed. UK/USA: Springer. 2012. 516 .

INSTITUTO ESTADUAL DO AMBIENTE - INEA. Relatório anual de qualidade do ar do ano de 2009. Rio de Janeiro: INEA, 2009.

LIN, C.A.; MARTINS, M.A.; FARHAT, S.C.; POPE, C.A.; CONCEICAO, G.M.; ANASTACIO, V.M.; HATANAKA, M. ANDRADE, W.C.; HAMAUE, W.R.; BOHM, G.M.; SALDIVA, P.H. Air pollution and respiratory illness of children in Sao Paulo, Brazil. Paediatr Perinat Epidemiol 13, 1999, 475-488.1999.

MARANDOLA JR, E. Tangenciando a vulnerabilidade. In: HOGAN, D. J.; MARANDOLA JR, E. (org.) Populações e mudanças climáticas: dimensões humanas das mudanças ambientais globais, p.: 29-52 CAMPINAS: NEPO/Unicamp; Brasília: UNFPA, 2009.

MARTINS, L. C.; et al. Poluição atmosférica e atendimentos por pneumonia e gripe em São Paulo, Brasil. Revista de Saúde Pública, vol. 36, nº 1, 88-94, São Paulo, 2002.

MONTEIRO, C. A. F. Teoria e Clima Urbano. Tese de Livre Docência. São Paulo: Instituto de GeociênciasUSP, 1976, $181 \mathrm{p}$.

RHODEN, C.R.; WELLENIUS, G.A.; GHELFI, E.; LAWRENCE, J.; GONZALEZ-FLECHA, B. PMinduced cardiac oxidative stress and dysfunction are mediated by autonomic stimulation. Biochim Biophys Acta 1725, 2005, p.p.:305-313.

SANT'ANNA NETO, J. L. Por uma Geografia do Clima: Antecedentes históricos, paradigmas contemporâneos e uma nova razão para um novo conhecimento. In: Terra Livre. N. 17, p.: 49-62, 2001.

SODRE, F.; FRAIFRELD, F. Poluição do ar e a saúde respiratória no município de Duque de Caxias. Revista Territorium, Coimbra, Portugal, n. 17, p. 47-57, 2010.

VESKOUKIS, A.S.; NIKOLAIDIS, M.G.; KYPAROS, A.; KOURETAS, D. Blood eflects tissue oxidative stress depending on biomarker and tissue studied. Free Radic Biol Med. 2009.

WORLD HEALTH ORGANIZATION - WHO. Reducing global health risks through mitigation of shortlived climate pollutants: Scoping report for policymakers. Genebra: WHO, 2015, 148 p. 